\title{
Mutu Sensoris Dan Sifat Fisik Nugget Ayam Yang Ditambahkan Tepung Ubi Jalar Ungu (Ipomoea batatas L)
}

\author{
F.S. Ratulangi dan S.C. Rimbing \\ Fakultas Peternakan Universitas Sam Ratulangi Manado, 95115 \\ Korespondensi (corresponding author): frietssr@unsrat.ac.id
}

\begin{abstract}
ABSTRAK
Penelitian ini bertujuan untuk mengetahui manfaat penggunaan tepung ubi jalar ungu (Ipomoea batatas L) terhadap mutu sensorik dan sifat fisik nugget ayam. Penelitian dilakukan dalam 3 tahap yaitu (1) pembuatan tepung ubi jalar ungu, (2) pembuatan nuget ayam dengan penambahan tepung ubi jalar ungu, (3) pengujian nuget ayam meliputi uji mutu sensoris menggunakan 35 panelis tidak terlatih untuk melihat tingkat penerimaan terhadap aroma, warna, tekstur dan citarasa, uji sifat fisik untuk mengetahui daya mengikat air dan susut masak. Penelitian ini dilaksanakan secara eksperimen menggunakan Rancangan Acak Lengkap dengan 4 perlakuan penambahan tepung ubi jalar ungu yaitu $\mathrm{P}_{1}=10 \mathrm{~g}, \mathrm{P}_{2}=20 \mathrm{~g}, \mathrm{P}_{3}=30 \mathrm{~g}$ dan $\mathrm{P}_{4}=40 \mathrm{~g}$, masing-masing perlakuan diulang sebanyak 35 (panelis) untuk uji mutu sensoris dan 5 ulangan untuk uji sifat fisik. Data hasil pengamatan uji mutu sensoris, sifat fisik ditabulasi dan dianalisis dengan analisis sidik ragam dan apabila terdapat perbedaan nyata antar perlakuan dilanjutkan dengan uji berganda Duncan (DMRT). Hasil penelitian dengan analisis sidik ragam menunjukan bahwa perlakuan penambahan ubi jalar ungu 10, 20, 30 dan 40 g memberikan pengaruh yang berbeda sangat nyata $(\mathrm{P}<0.01)$ terhadap warna, tekstur, daya mengikat air dan susut masak tapi memberikan pengaruh yang tidak berbeda nyata $(\mathrm{P}>0,05)$ terhadap aroma dan cita rasa. Hasil uji lanjut berganda Duncan menunjukan perlakuan P4 yakni $40 \mathrm{~g}$ Ubi jalar ungu memberikan hasil terbaik pada warna, tekstur, daya mengikat air dan susut masak. Berdasarkan hasil dan pembahasan dapat disimpulkan bahwa penambahan tepung ubi jalar ungu $40 \mathrm{~g}$ dalam pembuatan nuget daging ayam memberikan mutu sensorik dan sifat fisik yang baik.
\end{abstract}

Kata kunci : Nuget ayam, tepung ubi jalar ungu, mutu sensoris, sifat fisik.

\begin{abstract}
SENSORICAL QUALITY AND PHYSICAL PROPERTIES OF CHICKEN NUGGETS WHICH IS ADDED PURPLE ROAD UBI FLOUR (Ipomoea batatas L). This study aims to determine the benefits of using purple sweet potato flour (Ipomoea batatas L) on the sensory quality and physical properties of chicken nuggets. The research was carried out in 3 stages, namely (1) making purple sweet potato flour, (2) making chicken nugets with the addition of purple sweet potato flour, (3) testing chicken nuggets including sensory quality testing using 35 untrained panelists to measure the level of acceptance of aroma, color, texture and taste, physical properties test to determine water binding power and cooking losses. This research was conducted experimentally using a completely randomized design with 4 additional treatments of purple sweet potato flour, namely P1 $=10 \mathrm{~g}, \mathrm{P} 2=20 \mathrm{~g}, \mathrm{P} 3=30 \mathrm{~g}$ and P4 $=40 \mathrm{~g}$, each treatment was repeated as many as 35 (panelists) for the test. sensory quality and 5 replications for physical characteristics test. Data from the observation of sensory quality test, physical properties were tabulated and analyzed by analysis of variance (Ansira) and if there were significant differences between treatments, it was continued with Duncan's multiple test (DMRT). The results of the research with analysis of variance showed that the addition of 10 , 20,30 and 40 grams of purple sweet potato had a very significant effect $(\mathrm{P}<0.01)$ on color,
\end{abstract}


texture, water-binding capacity and cooking loss but had no significant effect. $(\mathrm{P}>0.05)$ on aroma and taste. The results of Duncan's multiple further test showed that the P4 treatment of $40 \mathrm{~g}$ of purple sweet potato gave the best results on color, texture, water binding power and cooking loss. Based on the results and discussion, it can be concluded that the addition of $40 \mathrm{~g}$ of purple sweet potato flour in the manufacture of chicken nuggets provides good sensory quality and physical properties.

Keywords: Chicken nuggets, purple sweet potato flour, sensory quality, physical properties

\section{PENDAHULUAN}

Daging mempunyai manfaat besar bagi manusia, karena merupakan makanan yang bergizi tinggi yaitu kaya akan protein, mineral, vitamin dan lemak serta zat-zat lain yang kesemuanya sangat dibutuhkan tubuh. Adanya peningkatan ekonomi masyarakat yang disertai dengan kesadaran akan pentingnya protein hewani, maka hal tersebut memacu peningkatan kebutuhan konsumsi daging bagi masyarakat. Daging ayam merupakan salah satu bahan pangan protein hewani yang memiliki nilai gizi tinggi, memiliki cita rasa yang baik, serta mudah diperoleh dalam bentuk segar (Wijayanti et al., 2013). Namun daging ayam cepat rusak karena mudah terkontaminasi dengan mikroba, maka salah satu cara yang ditempuh untuk mencegah kerusakan pada daging ayam yaitu dengan pengolahan menjadi produk nugget.

Nugget merupakan produk olahan daging giling yang ditambahkan bahan pengikat dan dicampur dengan bumbubumbu kemudian diselimuti oleh putih telur (batter) dan tepung panir (breading) kemudian dilakukan pre-frying lalu dikemas dan dibekukan untuk mempertahankan mutu (Mawati et al., 2017). Nugget ayam semakin dikenal sebagai makanan olahan daging bergizi tinggi dan ketersediaannya di supermarketsupermarket relatif banyak dan semakin disukai konsumen (Astriani et al., 2013; Komansilan, 2015).

Mutu produk makanan seperti nugget ayam sangat dipengaruhi oleh beberapa faktor antara lain rasa, warna, tekstur, nilai gizi, dan mikrobiologisnya. Warna merupakan faktor pertama penentu mutu nugget ayam secara visual yang memegang peranan penting terhadap penerimaan konsumen, hal ini disebabkan karena warna merupakan salah satu karakteristik sensoris yang paling mudah terdeteksi oleh konsumen dibandingkan dengan karakteristik sensoris lainnya seperti aroma dan tekstur (Nisa, 2013; Permadi et al., 2012). Nugget yang bernilai gizi baik, enak, dan teksturnya sangat baik tidak akan diterima oleh konsumen apabila memiliki warna yang menyimpang dari seharusnya (Ratulangi et al., 2017).

Umumnya tepung yang digunakan sebagai bahan pengikat dalam pembuatan nugget ayam adalah bahan berpati seperti tepung tapioka, tepung beras, tepung maezena, tepung sagu dan tepung terigu. Disisi lain, makanan pokok untuk masyarakat idealnya bersumber dari bahan baku lokal agar biayanya dapat ditekan (Kusumaningrum et al., 2013).

Ubi jalar ungu memiliki kandungan gizi yang kaya akan vitamin (B1, B2, C dan $\mathrm{E})$, mineral $(\mathrm{Ca}, \mathrm{Mg}, \mathrm{K}$ dan $\mathrm{Zn})$, serat makanan dan karbohidrat (Nurdjana dan Yuliana, 2019). Karena kemampuan mengikat airnya yang tinggi, maka tepung ubi jalar ungu dapat digunakan sebagai bahan pengikat dalam pembuatan produk olahan pangan. Selain itu ubi jalar ungu memiliki warna ungu yang cukup pekat karena adanya pigmen ungu antosianin yang menyebar dari bagian kulit sampai bagian daging ubinya (Santoso dan Estiasih, 2014; Lanusu et al., 2017). Ubi jalar ungu mengandung antosianin berkisar $\pm 519 \mathrm{mg} / 100 \mathrm{~g}$ berat basah. Kandungan antosianin yang tinggi pada ubi jalar tersebut dan stabilitas yang tinggi 
dibanding anthosianin dari sumber lain, membuat tanaman ini sebagai pilihan yang lebih sehat dan sebagai alternatif pewarna alami (El Husna el al., 2013; Rijal et al., 2019).

Penambahan tepung ubi jalar ungu dapat meningkatkan mutu sensorik dan mempengaruhi sifat fisik dari nugget ayam yang dihasilkan. Diversifikasi olahan nugget ayam dengan menambahkan tepung ubi jalar ungu sebagai bahan pengikat diharapkan menjadi bentuk keanekaragaman penyajian nugget ayam yang disukai konsumen.

Adapun tujuan penelitian ini untuk mengetahui manfaat penggunaan tepung ubi jalar ungu (Ipomoea batatas L) terhadap mutu sensorik dan sifat fisik nugget ayam, sehingga diharapkan dapat memberikan nilai tambah bagi bahan pangan lokal yaitu tepung ubi jalar ungu yang belum termanfaatkan secara optimal, sehingga menjadi bahan pangan yang bermutu dan bernilai ekonomis yang disukai konsumen.

\section{MATERI DAN METODE PENELITIAN}

Materi yang digunakan pada penelitian yaitu $1200 \mathrm{~g}$ daging ayam segar bagian dada dan $100 \mathrm{~g}$ tepung ubi jalar ungu. Alat yang digunakan yaitu mixer, alat pengiling daging, timbangan digital, kompor gas, loyang, piring, thermometer, dan alat uji organoleptik yaitu tissue, aqua dan kertas format uji sensoris dan alat tulis.

Penelitian ini dilaksanakan secara eksperimen menggunakan Rancangan Acak Lengkap dengan 4 perlakuan penambahan tepung ubi jalar ungu yaitu $\mathrm{P}_{1}$ $=10 \mathrm{~g}, \mathrm{P}_{2}=20 \mathrm{~g}, \mathrm{P}_{3}=30 \mathrm{~g}$ dan $\mathrm{P}_{4}=40 \mathrm{~g}$, deengan 35 panelis sebagai ulangan (Soekarto dan Hubeis, 1992 dalam Ratulangi et al., 2017) untuk uji mutu sensoris dan 5 ulangan untuk uji sifat fisik (Steel dan Torrie, 1995 dalam Mawati et al., 2017)

Data hasil pengamatan uji mutu sensoris, sifat fisik ditabulasi dan dianalisis dengan analisis sidik ragam dan apabila terdapat perbedaan nyata antar perlakuan dilanjutkan dengan uji berganda Duncan (Setyaningsih et al., 2010).

Variabel yang diamati pada penelitian ini yaitu mutu sensoris (aroma, warna, tekstur dan citarasa), dan sifat fisik (daya mengikat air dan susut masak).

\section{Prosedur Pengukuran Variabel Aroma}

Aroma sosis ubi jalar ungu diuji secara sensorik. Prosedur pengujian untuk aroma yaitu panelis mengambil nugget ayam dengan penambahan ubi jalar ungu yang telah disiapkan kemudian panelis menghirup aroma dari nugget ayam dengan penambahan ubi jalar ungu tersebut, lalu mengisi lembaran format uji sesuai dengan tingkat kesukaan (Rahayu, 2001 dalam Sasahan et al., 2017). Kriteria hedonik aroma nugget ayam dengan penambahan ubi jalar ungu adalah sebagai berikut: $5=$ Sangat suka, $4=$ Suka, $3=$ Agak suka, $2=$ Tidak suka, dan $1=$ Sangat tidak suka.

\section{Warna}

Sampel yang diuji ditempatkan di dalam wadah dan setiap sampel diberi kode. Panelis diminta untuk mengamati warna sampel nugget ayam dengan penambahan ubi jalar ungu tersebut, lalu mengisi lembaran format uji sesuai dengan tingkat ketertarikan warna (Rahayu, 2001 dalam Sasahan et al., 2017). Kriteria hedonik warna nugget ayam dengan penambahan ubi jalar ungu adalah sebagai berikut: $5=$ Sangat menarik, $4=$ Menarik, $3=$ Agak menarik, 2 = Tidak menarik, dan 1 = Sangat tidak menarik

\section{Tekstur}

Prosedur pengujian untuk tekstur yaitu panelis mengambil sampel nugget ayam dengan penambahan ubi jalar ungu menilai kekasaran dan kehalusan nugget, dengan cara perabaan dan penekanan, lalu mengisi lembaran format uji sesuai dengan tingkat rasa halus (Soekarto dan Hubeis, 1992 dalam Ratulangi et al., 2017). Kriteria hedonik tekstur nugget ayam dengan penambahan ubi jalar ungu adalah sebagai berikut : $5=$ Sangat halus, $4=$ halus, $3=$ 


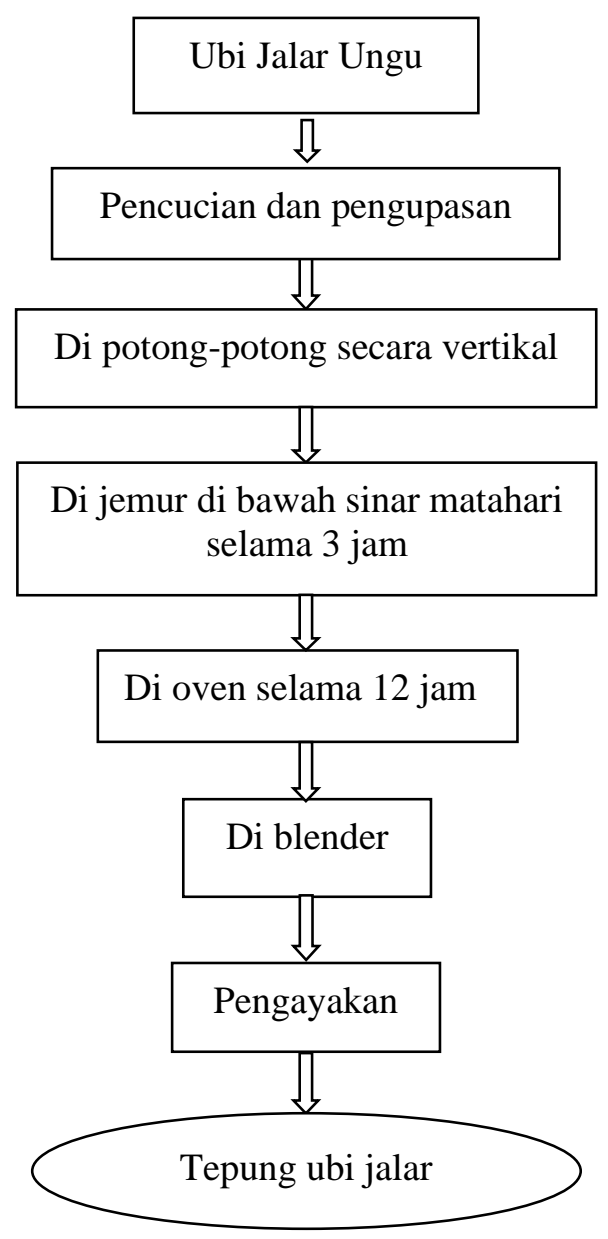

Gambar 1. Diagram alir pembuatan tepung ubi jalar ungu

agak halus, 2 = Tidak halus, dan $1=$ Sangat tidak halus

\section{Cita Rasa}

Cita rasa nugget ayam dengan penambahan ubi jalar ungu diuji secara sensosrik. Bahan disiapakan secara acak setiap pindahan sampel berikut didahului dengan meminum air putih dan memakan mentimun untuk menetralkan alat indra dalam rongga mulut. Selanjutnya, panelis mengambil nugget ayam dengan penambahan ubi jalar ungu yang telah disajikan, kemudian sampel diambil dan dicicipi, lalu mengisi lembaran format uji sesuai dengan tingkat rasa enak (Rahayu, 2001 dalam Sasahan et al, 2017). Kriteria hedonik cita rasa nugget ayam dengan penambahan ubi jalar ungu adalah sebagai berikut: $5=$ Sangat enak, $4=$ Enak, $3=$ Agak enak, 2 = Tidak enak, dan 1 = Sangat tidak enak.

\section{Daya Mengikat Air}

Pengukuran daya mengikat air ditentukan dengan menggunakan metode pengepresan dari Hamm (1972) dalam Sofiana (2012) yaitu dengan menggunakan alat Carver press. Sampel nugget ayam kurang lebih $0,3 \mathrm{~g}$ untuk masing-masing perlakuan diletakkan dikertas saring, kemudian dijepit diantara 2 kaca dan ditekan dengan beban $35 \mathrm{~kg}$ setiap $\mathrm{cm} 2$ selama 5 menit. Luas area basah (wetted area) adalah luas air yang diserap kertas saring akibat penjepitan, yaitu selisih luas 
lingkaran dilakukan dengan planimeter merk Hruden. Kertas saring yang digunakan adalah Whatman -1 No 41. Bobot air bebas (air daging yang terlepas karena proses penekanan) dapat dihitung dengan rumus sebagai berikut:

$$
\begin{gathered}
\mathrm{Mg} \mathrm{H} 2 \mathrm{O}=\frac{\text { Luas area basah }}{0,0948}-8,0 \\
\% \text { air bebas }=\frac{\mathrm{Mg} \mathrm{H} 2 \mathrm{O}}{300 \mathrm{mg}} \times 100
\end{gathered}
$$

Dengan mengetahui kadar air total daging (hasil analisis proksimat) maka kadar air terikat atau WHC dapat ditentukan WHC = kadar air total (\%) - kadar air bebas (\%).

Susut Masak

Pengukuran susut masak dilakukan dengan metode Houton et al. (1976) dalam Komansilan (2015). Disiapkan sampel

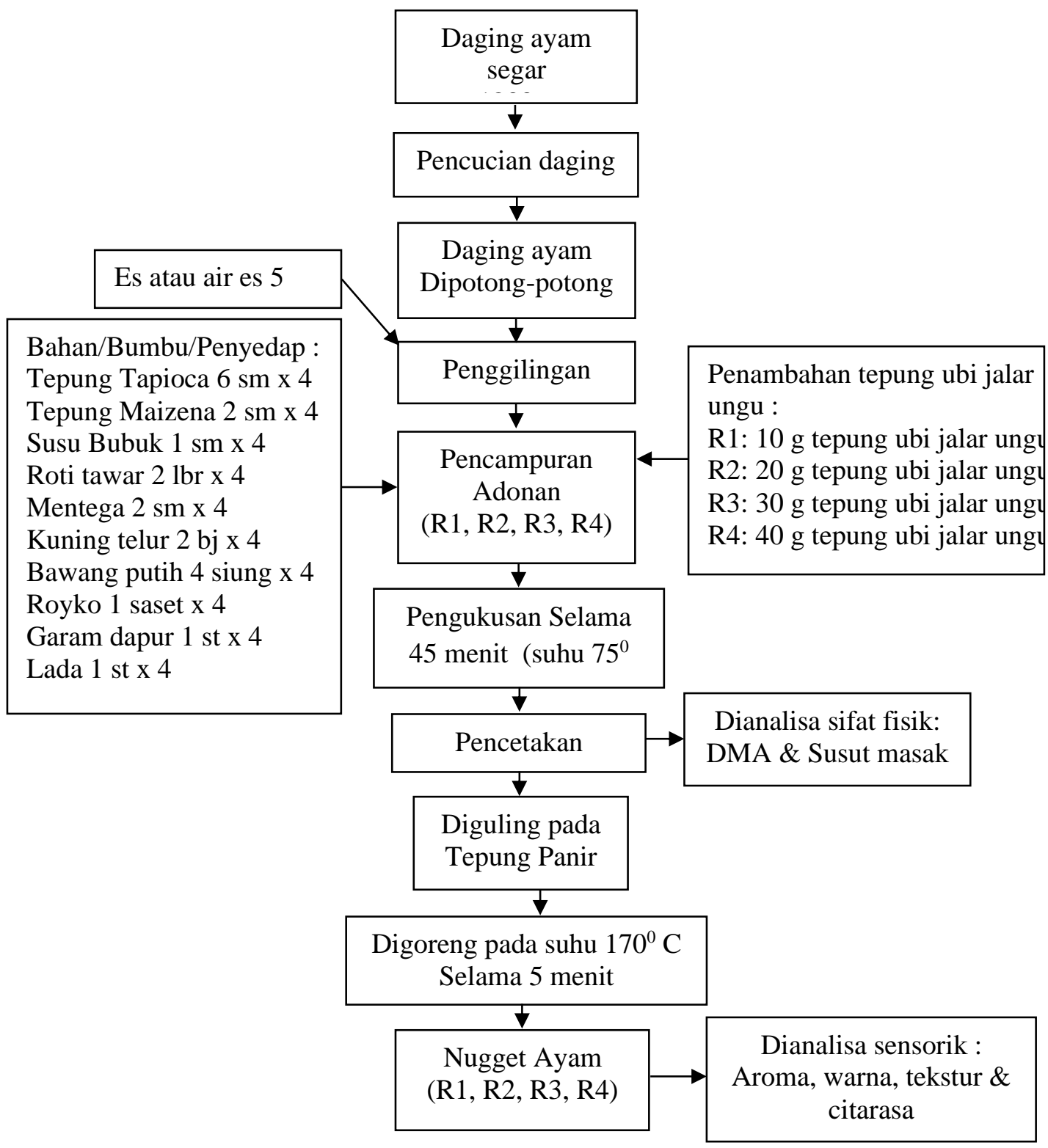

Gambar 2. Diagram alir pembuatan nugget/prosedur penelitian 
adonan nugget sebanyak $10 \mathrm{~g}$ untuk masing-masing perlakuan ditimbang $(\mathrm{x})$ kemudian dilakukan pemasakan pada suhu $75^{\circ} \mathrm{C}$ selama 45 menit. Cairan daging yang ada dipisahkan dan sampel daging dikeringkan dengan kertas peresap agar air yang menempel pada permukaan daging meresap, kemudian dilakukan penimbangan sampel (y). Selisih berat sampel sebelum dan sesudah pemasakan disebut sebagai susut masak yang dinyatakan dalam persen. Perhitungan susut masak dilakukan dengan menggunakan rumus:

$$
\text { Susut masak }(\%)=\frac{\mathrm{x}-\mathrm{y}}{\mathrm{X}} \times 100
$$

$\mathrm{x}=$ berat sampel sebelum dimasak $\mathrm{y}=$ berat sampel sesudah dimasak

\section{HASIL DAN PEMBAHASAN}

Hasil pengamatan mutu sensorik nugget daging ayam dengan penambahan ubi jalar ungu disajikan dalam Tabel 1.

\section{Aroma nugget}

Data hasil pengamatan menunjukkan bahwa rataan tingkat kesukaan panelis terhadap aroma nugget ayam dengan penambahan tepung ubi jalar ungu pada level yang berbeda berkisar antara 3,83 (suka) sampai 4,14 (suka). Nilai rataan skor tertinggi diperoleh pada perlakuan $\mathrm{P} 3$ yakni penambahan tepung ubi jalar ungu $30 \mathrm{~g}$ dan terendah pada perlakuan $\mathrm{P} 4$ dengan penambahan $40 \mathrm{~g}$ tepung ubi jalar ungu. Hasil analisis sidik ragam, menunjukkan bahwa perlakuan penambahan tepung ubi jalar ungu $10-40 \mathrm{~g}$ memberikan pengaruh berbeda tidak nyata $(\mathrm{P}>0,05)$ terhadap nugget ayam. Diduga bahwa aroma yang ditimbulkan dengan penambahan tepung ubi jalar ungu 10 - $40 \mathrm{~g}$ tidak menyebabkan perbedaan penciuman panelis terhadap produk nugget ayam. Hal ini sesuai dengan pendapat Hakim (2013) menyatakan bahwa aroma yang ditimbulkan oleh makanan merupakan daya tarik yang sangat kuat dan mampu merangsang indera penciuman sehingga membangkitkan selera.

\section{Warna nugget}

Data hasil pengamatan menunjukkan bahwa rataan penilaian panelis terhadap warna nugget ayam dengan penambahan tepung ubi jalar ungu pada level yang berbeda berkisar antara 3,46 (agak menarik) sampai 4,54 (menarik). Nilai rataan skor tertinggi diperoleh pada perlakuan P3 yakni penambahan tepung ubi jalar ungu $30 \mathrm{~g}$ dan terendah pada perlakuan P1 dengan penambahan $10 \mathrm{~g}$ tepung ubi jalar ungu. Hasil analisis sidik ragam, menunjukkan bahwa perlakuan penambahan tepung ubi jalar ungu $10-40$ $\mathrm{g}$ memberikan pengaruh berbeda sangat nyata $(\mathrm{P}<0,01)$ terhadap nugget ayam. Berdasarkan hasil uji lanjut DMRT menunjukkan bahwa perlakuan P3 berbeda tidak nyata $(\mathrm{P}>0,05)$ dengan perlakuan $\mathrm{P} 4$ tetapi berbeda nyata $(\mathrm{P}<0,05)$ dengan $\mathrm{P} 2$ dan P1. Perlakuan P4 berbeda nyata $(\mathrm{P}<0,05)$ dengan perlakuan $\mathrm{P} 2$ dan $\mathrm{P} 1$ tetapi perlakuan $\mathrm{P} 2$ berbeda tidak nyata $(\mathrm{P}>0,05)$ dengan perlakuan P1. Data hasil uji mutu sensorik warna nugget menunjukan bahwa penambahan tepung ubi jalar ungu $30 \mathrm{~g}$ lebih disukai panelis dibandingkan yang ditambahkan 10, 20 dan $40 \mathrm{~g}$ tepung ubi

Tabel 1. Rataan Mutu Sensorik Nugget Ayam dengan Penambahan Ubi Jalar Ungu

\begin{tabular}{lcccc}
\hline \multirow{2}{*}{ Variabel } & \multicolumn{4}{c}{ Perlakuan } \\
\cline { 2 - 5 } & P1 $(10 \mathrm{~g})$ & P2 $(20 \mathrm{~g})$ & P3 $(30 \mathrm{~g})$ & P4 $(40 \mathrm{~g})$ \\
\hline Aroma & $4,08^{\mathrm{a}}$ & $3.88^{\mathrm{a}}$ & $4,14^{\mathrm{a}}$ & $3,83^{\mathrm{a}}$ \\
Warna & $3,46^{\mathrm{a}}$ & $3,66^{\mathrm{b}}$ & $4,54^{\mathrm{c}}$ & $4,34^{\mathrm{d}}$ \\
Tekstur & $3,88^{\mathrm{a}}$ & $3,94^{\mathrm{b}}$ & $4,03^{\mathrm{c}}$ & $3,46^{\mathrm{d}}$ \\
Cita Rasa & $4,08^{\mathrm{a}}$ & $4,06^{\mathrm{a}}$ & $4,31^{\mathrm{a}}$ & $4,11^{\mathrm{a}}$ \\
\hline
\end{tabular}

Keterangan: Superskrip berbeda pada baris yang sama artinya berbeda sangat nyata $(\mathrm{P}<0,01)$ 
jalar ungu. Penerimaan panelis terhadap warna nugget diduga karena tepung ubi jalar ungu mengandung pigmen antosianin yang memberikan warna ungu pada nugget. Daya tarik warna ungu yang ditampilkan pada perlakuan $30 \mathrm{~g}$ memberikan kesan yang menarik dibandingkan dengan warna ungu pada perlakuan 10, 20 dan $40 \mathrm{~g}$. Menurut Samber (2013) menyatakan kandungan antosianin yang tinggi pada ubi dibanding antosianin dari sumber lain. Tepung ubi jalar ungu memiliki warna ungu yang cukup pekat karena adanya pigmen ungu antosianin. Itulah sebabnya tanaman ini menjadi pilihan yang lebih sehat dan sebagai alternatif pewarnaan alami. Selanjutnya Hakim (2013)menyatakan bahwa antosianin merupakan pigmen alami yang berpotensi memberikan warna alami sehingga menghasilkan penampilan yang menarik pada produk olahan. Warna alami dari tepung ubi jalar ungu memberikan intensitas warna ungu yang stabil.

\section{Tekstur nugget}

Data hasil pengamatan menunjukkan bahwa rataan penilaian panelis terhadap tekstur nuget ayam dengan penambahan tepung ubi jalar ungu pada level yang berbeda berkisar antara 3,46 (agak halus) sampai 4,03 (halus). Nilai rataan skor tertinggi diperoleh pada perlakuan P3 yakni penambahan tepung ubi jalar ungu $30 \mathrm{~g}$ dan terendah pada perlakuan $\mathrm{P} 4$ dengan penambahan $40 \mathrm{~g}$ tepung ubi jalar ungu. Hasil analisis sidik ragam, menunjukkan bahwa perlakuan penambahan tepung ubi jalar ungu $10-40 \mathrm{~g}$ memberikan pengaruh berbeda sangat nyata $(\mathrm{P}<0,01)$ terhadap nugget ayam. Berdasarkan hasil uji lanjut DMRT menunjukkan bahwa perlakuan P3 berbeda tidak nyata $(\mathrm{P}>0,05)$ dengan perlakuan $\mathrm{P} 2$ dan $\mathrm{P} 1$ tetapi berbeda nyata dengan P4. Perlakuan P2 berbeda nyata $(\mathrm{P}<0,05)$ dengan perlakuan $\mathrm{P} 4$ tetapi berbeda tidak nyata $(\mathrm{P}>0,05)$ dengan $\mathrm{P} 1$ demikian juga perlakuan $\mathrm{P} 1$ berbeda nyata $(\mathrm{P}<0,05)$ dengan perlakuan $\mathrm{P} 4$. Data hasil uji mutu sensorik tekstur nugget menunjukan bahwa penambahan tepung ubi jalar ungu $30 \mathrm{~g}$ lebih disukai panelis dibandingkan yang ditambahkan 10, 20 dan $40 \mathrm{~g}$ tepung ubi jalar ungu. Penerimaan panelis terhadap kehalusan tekstur nugget diduga karena ukuran partikel tepung ubi jalar ungu relatif sama dengan tepung lainya yang digunakan dalam pembuatan nugget ayam dan memiliki karbohidrat kompleks. Menurut Hakim (2013); Nurdjana dan Yuliana, (2019). bahwa unsur karbohidrat pada tepung ubi jalar ungu pada proses pembuatan nugget berfungsi meningkatkan tekstur dan menstabilkan daya ikat air yang berpengaruh pada tekstur nugget. Kehalusan tekstur pada nugget sangat dipengaruhi oleh komposisi campuran, pengolahan dan penyimpanan.

\section{Citarasa nugget}

Data hasil pengamatan menunjukkan bahwa rataan penilaian panelis terhadap citarasa nuget ayam dengan penambahan tepung ubi jalar ungu pada level yang berbeda berkisar antara 4,06 (suka) sampai 4,31 (suka). Nilai rataan skor tertinggi diperoleh pada perlakuan P3 yakni penambahan tepung ubi jalar ungu $30 \mathrm{~g}$ dan terendah pada perlakuan P2 dengan penambahan $20 \mathrm{~g}$ tepung ubi jalar ungu. Hasil analisis sidik ragam, menunjukkan bahwa perlakuan penambahan tepung ubi jalar ungu 10 - $40 \mathrm{~g}$ memberikan pengaruh berbeda tidak nyata $(\mathrm{P}>0,05)$ terhadap nugget ayam. Diduga bahwa perlakuan penambahan tepung ubi jalar ungu 10 - 40 $\mathrm{g}$ belum menyebabkan perbedaan bau dan rasa bagi penilaian panelis terhadap citarasa nuget ayam. Hal ini sejalan dengan pendapat Winarno (2002) bahwa citarasa bahan pangan sesungguhnya terdiri dari 3 komponen pokok yaitu bau, rasa, dan rangsangan mulut. Bau menentukan kelezatan bahan makanan, rasa lebih banyak melibatkan panca indera lidah dengan pengindraan kecapan pada rasa asin, asam, manis dan pahit, sedangkan rangsangan mulut merupakan timbulnya perasaan seseorang setelah menelan bahan makan. 
Tabel 2. Rataan Sifat Fisik Nugget Ayam dengan Penambahan Ubi Jalar Ungu

\begin{tabular}{lcccc}
\hline \multirow{2}{*}{ Variabel } & \multicolumn{4}{c}{ Perlakuan } \\
\cline { 2 - 5 } & P1 $(10 \mathrm{~g})$ & P2 $(20 \mathrm{~g})$ & P3 $(30 \mathrm{~g})$ & P4 $(40 \mathrm{~g})$ \\
\hline Daya Mengikat Air & $61,47^{\mathrm{a}}$ & $60,35^{\mathrm{b}}$ & $55,38^{\mathrm{c}}$ & $51,28^{\mathrm{d}}$ \\
Susut Masak & $1,50^{\mathrm{a}}$ & $1,56^{\mathrm{b}}$ & $1,61^{\mathrm{c}}$ & $1,62^{\mathrm{d}}$ \\
\hline
\end{tabular}

Keterangan: Superskrip berbeda pada baris yang sama artinya berbeda sangat nyata $(\mathrm{P}<0,01)$

Hasil pengamatan sifat fisik nugget daging ayam dengan penambahan ubi jalar ungu disajikan dalam Tabel 2.

\section{Daya mengikat air nugget}

Data hasil pengamatan rataan daya mengikat air nuget ayam dengan penambahan tepung ubi jalar ungu pada level yang berbeda berkisar antara 51,28 $61,47 \%$. Nilai rataan daya mengikat air tertinggi diperoleh pada perlakuan P1 $(61,47 \%)$ yakni penambahan tepung ubi jalar ungu $10 \mathrm{~g}$ dan terendah pada perlakuan P4 $(51,28 \%)$ dengan penambahan $40 \mathrm{~g}$ tepung ubi jalar ungu. Hasil analisis sidik ragam, menunjukkan bahwa perlakuan penambahan tepung ubi jalar ungu $10-40$ g memberikan pengaruh berbeda sangat nyata $(\mathrm{P}<0,01)$ terhadap daya mengiat air nugget ayam. Berdasarkan hasil uji lanjut DMRT menunjukkan bahwa perlakuan P1 berbeda nyata $(\mathrm{P}<0,05)$ dengan perlakuan P2, P3 dan P4. Perlakuan P2 berbeda nyata $(\mathrm{P}<0,05)$ dengan perlakuan $\mathrm{P} 3$ dan $\mathrm{P} 4$ demikian juga perlakuan $\mathrm{P} 3$ berbeda nyata $(\mathrm{P}<0,05)$ dengan perlakuan $\mathrm{P} 4$. Pengukuran data daya mengikat air menunjukkan bahwa semakin tinggi perlakuan penambahan tepung ubi jalar ungu semakin menurun daya mengikat air. Hal ini dikarenakan semakin tinggi level penambahan tepung ubi jalar, maka proporsi protein dalam nugget ayam semakin rendah, sehingga dengan menurunnya kadar protein akan menurunkan daya mengikat air. Protein berfungsi sebagai bahan pengikat dalam proses emulsi dan sebagai pengikat atau penahan air. Sebagaiman Lukman (1995) dalam Gumilar et al. (2011) menyatakan bahwa semakin banyak tepung yang ditambahkan ke dalam adonan maka kadar protein akan semakin sedikit sehingga daya mengikat air pun menurun.

\section{Susut masak nugget}

Data hasil pengamatan rataan susut masak nuget ayam dengan penambahan tepung ubi jalar ungu pada level yang berbeda berkisar antara 1,50-1,62\%. Nilai rataan susut masak tertinggi diperoleh pada perlakuan P4 $(1,62)$ yakni penambahan tepung ubi jalar ungu $40 \mathrm{~g}$ dan terendah pada perlakuan P1 (1,50) dengan penambahan $40 \mathrm{~g}$ tepung ubi jalar ungu.

Hasil analisis sidik ragam, menunjukkan bahwa perlakuan penambahan tepung ubi jalar ungu 10 - $40 \mathrm{~g}$ memberikan pengaruh berbeda sangat nyata $(\mathrm{P}<0,01)$ terhadap susu masak nugget ayam. Berdasarkan hasil uji lanjut DMRT menunjukkan bahwa perlakuan $\mathrm{P} 4$ berbeda nyata $(\mathrm{P}<0,05)$ dengan perlakuan P1 dan P2 tetapi berbeda tidak nyata dengan P3. Perlakuan P3 berbeda nyata $(\mathrm{P}<0,05)$ dengan perlakuan P1 dan P2 demikian juga perlakuan P2 berbeda nyata $(\mathrm{P}<0,05)$ dengan perlakuan P1. Pengukuran susut masak menunjukkan bahwa semakin tinggi perlakuan penambahan tepung ubi jalar ungu semakin meningkat susut masak. Hal ini dikarenakan semakin tinggi level penambahan tepung ubi jalar, maka proporsi protein dalam nugget ayam semakin rendah, sehingga daya mengikat air oleh protein daging akan menurun dan menyebabkan susut masak meningkat. Susut masak yang tinggi akan menyebabkan kandungan nutrisi yang terdapat dalam nugget akan berkurang sehingga kualitas nugget menurun. Hal ini sejalan dengan pendapat Soeparno (2005) bahwa daging dengan susut masak yang 
lebih rendah mempunyai kualitas yang relatif lebih baik daripada daging dengan susut masak lebih besar, karena kehilangan nutrisi selama pemasakan akan lebih sedikit.

\section{KESIMPULAN}

Berdasarkan hasil dan pembahasan dapat disimpulkan bahwa penambahan tepung ubi jalar ungu sampai $30 \mathrm{~g}$ menghasilkan mutu sensoris nugget ayam yang dapat diterima panelis dengan sifat fisik yang baik.

\section{DAFTAR PUSTAKA}

Afrianti, M., B. Dwiloka dan B.E. Setiani. 2013. Perubahan warna, profil protein, dan mutu organoleptik daging ayam broiler setelah direndam dengan ekstrak daun senduduk. Jurnal Aplikasi Teknologi Pangan 2(3): 116-120

Astriani, R.P., K. Kusrahayu dan S. Mulyani. 2013. Pengaruh berbagai filler (bahan pengisi) terhadap sifat organoleptik beef nugget. Animal Agriculture Journal 2(1): 247-252.

El Husna, N., M. Novita dan S. Royana. 2013. Kandungan antosianin dan aktivitas antioksidan ubi jalar ungu segar dan produk olahannya. Agritech 33(3): 296-302.

Gumilar, J., O. Rachmawan dan W. Nurdyanti. 2011. kualitas fisikokimia naget ayam yang menggunakan filler tepung suweg (Amorphohallus camponelatus B1). Jurnal Ilmu Ternak Vol. 11(1): 1-5

Hakim, U.N. 2013. Pengaruh Penambahan Tepung Garut (Maranta arrundinaceae) Terhadap Fisik Dan Organoleptik Nugget Kelinci. Disertasi. Universitas Brawijaya, Malang.

Komansilan, S. 2015. Pengaruh Penggunaan beberapa jenis Filler Terhadap Sifat Fisik Chicken Nugget
Ayam Petelur Afkir. Jurnal Zootek 35(1): 106-116.

Kusumaningrum, M., K. Kusrahayu dan S. Mulyani. 2013. Pengaruh berbagai filler (bahan pengisi) terhadap kadar air, rendemen dan sifat organoleptik (warna) chicken nugget. Animal Agriculture Journal 2(1): 370-376.

Lanusu, A., S.E. Surtijono, L.C.M. Karisoh, E.H.B. Sondakh. 2017. Sifat organoleptik es krim dengan penambahan ubi jalar ungu (Ipomea batatas L). Jurnal Zootek 37(2): 474 482

Mawati, A., E.H.B. Sondakh, J.A.D. Kalele, R. Hadju, 2017. Kualitas chicken nugget yang difortifikasi dengan tepung kacang kedelai untuk peningkatan serat pangan (dietary fiber). Jurnal Zootek Vol 37 (2): 464 473

Nisa, T.K. 2013. Pengaruh Subtitusi Nangka Muda (Artocaprus heterophillus LMK) Terhadap Kualitas Organoleptik Nugget Ayam. Food Science and Culinary Education Journal 2(1): 63-71

Nurdjanah, S. dan N. Yuliana, 2019. Ubi Jalar Teknologi Produksi dan Karakteristik Tepung Ubi Jalar Ungu Termodifikasi. Penerbit CV. Anugerah Utama Raharja, Bandar Lampung.

Permadi, S.N., S. Mulyani dan A. Hintono. 2012. Kadar serat, sifat organoleptik dan rendemen nugget ayam yang disubtitusi dengan Jamur Tiram Putih (Plerotus ostreatus). Jurnal Aplikasi Teknologi Pangan 1(4): 115-120

Ratulangi, Y.A., S.E Siswosubroto, F.S. Ratulangi dan J.E.G. Rompis. 2017. Sifat organoleptik naget ayam yang menggunakan tepung kedelai sebaai penggantian sebagian daging. Jurnal Zootek 38(1): 131-141

Rijal, M., N.A. Natsir dan I. Sere. 2019. Analisis kandungan zat gizi pada tepung Ubi Jalar Ungu (Ipomoea batatas var. Ayumuraseki) dengan 
pengeringan sinar matahari dan oven. Jurnal Biotek 7(1): 48-57.

Santoso, W.E.A. dan T. Estiasih. 2014. Kopingmentasi ubi jalar ungu (Ipomea Batatas Var. Ayamurasaki) dengan kopingmentasi na-kaseinat dan protein whey serta stabilitasnya terhadap pemanasan. Jurnal Pangan dan Agroindustri 2(4): 121-127

Sasahan, I., F.S. Ratulangi, M. Sompie dan J.E.G. Rompis. Penggunaan tepung Ubi Jalar Ungu (Ipomoea batatas L) sebagai filler terhadap sifat sensorik sosis daging ayam. Jurnal Zootek 41(1): 131-138.

Setyaningsih, D., A. Apriyantono dan M.P. Sari. 2010. Analisis Sensori untuk Industri Pangan dan Agro. Penerbit IPB Press, Bogor.
Soeparno. 2005. Pengolahan Hasil Ternak. Buku Materi Pokok. Edisi 2. Penerbit Universitas Terbuka.

Sofiana, A. 2012. Penambahan Tepung Protein Kedelai Sebagai Pengikat pada Sosis Sapi. Jurnal Ilmiah IlmuIlmu Peternakan 15(1): 1-7.

Steel, R.D. dan J.H. Torrie. 1994. Prinsip dan Prosedur Statistika Suatu Pendekatan Biometrik. Edisi kedua. Diterjemahkan oleh Bambang Sumantri Jakarta: PT. Gramedia.

Wijayanti, D.A., A. Hintono dan Y. B. Pramono. 2013. Kadar protein dan keempukan nugget ayam dengan berbagai level substitusi hati ayam broiler. Animal agriculture journal 2(1): 295-300.

Winarno, F.G. 2002. Kimia Pangan dan Gizi. Gramedia Pustaka Utama. Jakarta. 